\title{
Results of the validation of the pacte translation competence model: acceptability and decision making
}

\author{
PACTE GROUP \\ Allison Beeby, Mònica Fernández, Olivia Fox, Amparo Hurtado Albir, \\ Inna Kozlova, Anna Kuznik, Wilhelm Neunzig, Patricia Rodríguez, \\ Lupe Romero, Stefanie Wimmer (in alphabetical order) \\ Principal researcher: Amparo Hurtado Albir
}

\author{
Universitat Autònoma de Barcelona \\ Departament de Traducció i d'Interpretació \\ Edifici K, Campus UAB \\ 08193 Bellaterra (Barcelona), Spain \\ Tel.: +34-935812761; Fax: +34-935812762 \\ gr.pacte@uab.cat; www.fti.uab.es/pacte
}

\begin{abstract}
:
The PACTE Group is carrying out empirical-experimental research into translation competence and its acquisition in written translation. The aim of this article is to present the results obtained for the translation competence indicator 'Acceptability' of translation products and the variable "Decision-making" in an experiment involving 35 expert translators and 24 foreign-language teachers.

After a presentation of PACTE's theoretical model of Translation Competence, the design of our research project is described (hypothesis, experimental universe and sample, variables, data collection instruments). Then the results obtained for the indicator 'Acceptability' of subjects' translations and, finally, the results obtained for the variable "Decision-making" are presented. This variable evidences decisions made
\end{abstract}


during the translation process which involve the use of automatic and non-automatic cognitive resources (internal support) and the use of different sources of documentation (external support). The indicators used to measure this variable are 'Sequences of Actions' and 'Acceptability'. The results obtained shed light on the strategic and instrumental sub-competences of translation competence.

Key words: translation competence, empirical-experimental research, decisionmaking, acceptability

\section{INTRODUCTION}

PACTE has been carrying out empirical-experimental research into translation competence and its acquisition in written translation since October 1997. The first phase of our project - investigating translation competence - is almost complete, and we will soon begin our research into the acquisition of translation competence in translator trainees.

In preparation for our experiment to study translation competence, we carried out exploratory studies and pilot tests. The results of these have been published (cf. PACTE 2002, 2005a, 2005b). We are now analysing the latest data obtained from our experiment carried out with two experimental groups: one comprising 35 expert translators, and the other comprising 24 foreign-language teachers. This article gives a brief overview of our research design, and focuses on the results obtained for the dependent variable "Decision-making" and the indicator 'Acceptability'.

\section{THEORETICAL MODEL}

We define translation competence as the underlying system of knowledge required to translate. We believe that translation competence: (a) is expert knowledge; (b) is predominantly procedural; (c) comprises different inter-related sub-competences; and (d) includes a strategic component which is of particular importance.

In our model (cf. PACTE 2003), translation competence comprises five subcompetences as well as psycho-physiological components:

- Bilingual sub-competence. Predominantly procedural knowledge required to communicate in two languages. It comprises pragmatic, socio-linguistic, textual, grammatical and lexical knowledge. 
- Extra-linguistic sub-competence. Predominantly declarative knowledge, both implicit and explicit. It comprises general world knowledge, domain-specific knowledge, bicultural and encyclopaedic knowledge.

- Knowledge about translation. Predominantly declarative knowledge, both implicit and explicit, about translation and aspects of the profession. It comprises knowledge about how translation functions and knowledge about professional translation practice.

- Instrumental sub-competence. Predominantly procedural knowledge related to the use of documentation resources and information and communication technologies applied to translation (dictionaries of all kinds, encyclopaedias, grammars, style books, parallel texts, electronic corpora, search engines, etc.).

- Strategic sub-competence. Procedural knowledge to guarantee the efficiency of the translation process and solve problems encountered. This is an essential subcompetence that controls the translation process. Its function is to plan the process and carry out the translation project (selecting the most appropriate method); evaluate the process and the partial results obtained in relation to the final purpose; activate the different sub-competences and compensate for any shortcomings; identify translation problems and apply procedures to solve them.

- Psycho-physiological components. Different types of cognitive and attitudinal components and psycho-motor mechanisms, including cognitive components such as memory, perception, attention and emotion; attitudinal aspects such as intellectual curiosity, perseverance, rigour, the ability to think critically, etc.; abilities such as creativity, logical reasoning, analysis and synthesis, etc.

Given that we believe that translation is a problem-solving process, we consider strategic competence to be the most important of all the sub-competences that interact during the translation process.

\section{RESEARCH DESIGN}

We consider the sub-competences that are specific to translation competence to be: strategic competence, instrumental competence and knowledge of translation. Our research, therefore, focuses on these three competences. 


\subsection{Hypothesis}

Our general hypothesis is that the degree of expertise in translation (i.e. translation competence) is reflected in both the process and the product of translation. Given that a high degree of expertise in translation may be expected in experienced translators, the definition of expertise for the purposes of our study is based on: (a) years of experience as a translator; (b) translation as a main source of income; and (c) experience in translating a wide range of texts. Our empirical and working hypotheses were established based on the PACTE translation competence model (PACTE 2003).

\subsection{Experimental universe and sample}

The universe from which our sample is taken is that of professionals working with foreign languages. Two experimental groups were selected from this universe: expert translators and teachers of foreign languages.

The group of expert translators was required to have at least five years of experience translating in a variety of fields with translation as their main professional activity (at least $70 \%$ of their annual income). This does not mean that we consider expert translators to be only those that fulfil these criteria; translators with these characteristics were selected to ensure that the sample was homogenous and that the results of our experiment would not be biased by using translators specialised in specific fields.

The group of foreign-language teachers, on the other hand, had no experience in translating, but at least five years of experience in teaching in the Spanish Ministry of Education's Modern Language School (Escuela Oficial de Idiomas). The decision was made to select teachers of foreign languages because, whilst sharing some of the characteristics of expert translators, confounding variables (such as levels of linguistic and extralinguistic knowledge and being in contact with two languages) could be controlled.

All subjects were required to be native speakers of Spanish and/or Catalan and to work in a professional capacity with German, French or English as their foreign language. 
Thirty-five professional translators and 24 foreign-language teachers participated in the experiment. All fulfilled the selection criteria established. The translators included in the study had an average of seven and a half (7.51) years of experience in translating; the average percentage of their income from translating was $86.43 \%$; and their experience included translating a wide range of texts into their native language.

\subsection{Variables}

One independent variable and five dependent variables were selected for our study. The independent variable established was the degree of expertise in translation, defined in terms of years of experience in translating as the subject's main professional activity. The dependent variables were: (a) "Knowledge about Translation"; (b) "Efficacy of the Translation Process"; (c) "Decision-making"; (d) "Translation Project"; and (e) "Identification and Solution of Translation Problems". During the experiment a further variable "Use of Instrumental Resources" was added.

The following definitions were established for these variables and their indicators (PACTE 2007a, 2007b):

(a) "Knowledge about Translation": subjects' implicit knowledge of the principles of translation and aspects of the translation profession. The indicators of this variable are the 'Dynamic Index' and the 'Coherence Coefficient' of the subjects' concept of translation. The 'Dynamic Index' determines the degree to which the subjects' implicit knowledge about translation is associated with a more dynamic (textual, communicative and functional) or a more static (linguistic and literal) concept of translation. The 'Coherence Coefficient' determines whether or not the subjects' expressed opinions about their concept of translation are coherent. This variable is related to the subcompetence Knowledge about Translation.

(b) "Efficacy of the Translation Process": the optimum relationship between time taken to complete a translation task and the acceptability of the solution. Indicators of this variable are: the 'Total Time Taken' by the subjects to translate a text; the 'Time Taken at Each Stage' of the translation process: orientation, development (drafting), revision (based on the distinction made by Jakobsen 2002). This variable is related to strategic sub-competence. 
(c) "Decision-making": decisions made during the translation process which involve the use of automatic and non-automatic cognitive resources (internal support) and the use of different sources of documentation (external support) (Alves 1995, 1997). Indicators of this variable are 'Sequences of Actions' (see Section 4.2.1.). This variable provides data on subjects' procedural behaviour and is related to the strategic and instrumental subcompetences of translation competence. It is the most complex variable.

(d) "Translation Project": the mental representation or expectations of what the translation of a given text should be. Indicators of this variable are: the 'Dynamic Index' of the overall translation project and that of each Rich Point in the text to be translated (see Section 2.5.); as well as the 'Coherence Coefficient' of the overall translation project and that of each Rich Point. This variable is related to the strategic subcompetence.

(e) "Identification and Solution of Translation Problems": difficulties encountered by subjects when carrying out the translation task. Indicators of this variable are: 'Nature of Problem Identified'; 'Conceptualization of Problems'; the 'Problem-solving Procedure', as explained by subjects; the 'Degree of Satisfaction' with the solution found; the 'Degree of Difficulty' of the text. This variable is related to the strategic and knowledge about translation sub-competences.

(f) "Use of Instrumental Resources": Process during which documentation strategies are activated using resources in electronic format (Internet, dictionaries and encyclopaedias on CD-ROM). The indicators of this variable are: the 'Variety of Resources Used'; the 'Number of Searches'; and the 'Time Spent On Searches' (total and for each stage). This variable was added during the experiment given that marked differences were observed between experts and non-experts. It is related to the instrumental subcompetence.

Moreover, the indicator 'Acceptability', an all-purpose or 'transversal' indicator, is used in addition to specific indicators for each variable.

\subsection{Data collection}


Different types of instruments have been used to collect data about both the translation process and the product to allow triangulation of the results:

1. Texts and translations. Subjects were required to translate two texts: one from a foreign language into their native language (i.e. direct translation) and one from their native language into their foreign language (i.e. inverse translation).

2. Translation protocols: Translation protocols (Neunzig 2002) were recorded using the commercial software programs PROXY and Camtasia. PROXY is a program (compatible with Windows) designed for the remote control of computers and users connected to a network. Camtasia records subjects' actions on the computer in real time and stores these recordings for subsequent study and data analysis.

3. Direct observation. There was one researcher directly observing each subject during the translation process and taking notes to ensure that all data relating to the subjects' actions during the translation process were recorded, including those which could not be recorded electronically.

4. Questionnaires. Three types of questionnaires were developed: (1) an initial questionnaire used to ensure that the subjects selected for inclusion in the experimental groups fulfilled the selection criteria; (2) a translation problems questionnaire used to elicit information on the translation problems encountered during the process of translation; and (3) a questionnaire on knowledge about translation used to obtain information on the subjects' knowledge of translation.

5. Retrospective interviews. Retrospective interviews were designed to complete and contrast information obtained in the questionnaire on translation problems and the way in which they were solved.

Subjects performed the following tasks: (1) direct translation; (2) completion of a questionnaire about the problems encountered in the translation; (3) inverse translation; (4) completion of a questionnaire about the problems encountered in the translation; (5) completion of a questionnaire about translation knowledge; (6) participation in a retrospective interview.

\subsection{Rich Points}


Given that we consider translation to be a problem-solving process, the decision was made to focus our data collection and analysis on specific source-text segments that contained translation problems and that we refer to as Rich Points. These Rich Points were determined as a result of exploratory studies and pilot tests carried out prior to the experiment (PACTE 2002, 2005a, 2005b).

The use of Rich Points has the following methodological advantages:

1. Data may be collected on a range of different types of translation problems representative of those commonly found when translating.

2. In-depth analysis of the same Rich Point can be carried out using the results obtained from several indicators

3. The triangulation of data obtained from multiple sources is facilitated.

4. The same methods of data analysis can be used for direct translation and inverse translation in all language combinations involved in the experiment.

5. Greater economy is guaranteed in the experiment, and, as a result, data analysis made easier.

When identifying the Rich Points in each text, the following types of translation problems were taken into account:

- Linguistic problems: lexical (non-specialised) and morphosyntactic

- Textual problems: coherence, cohesion, text type and genre, style, intertextuality

- Extralinguistic problems: cultural, encyclopaedic and subject-domain knowledge

- Problems of intentionality: difficulty in understanding the source text (speech acts, presuppositions, implicatures)

- Problems relating to the translation brief and/or the target-text reader (affecting reformulation) which, from a functionalist point of view, would affect all the Rich Points

The texts selected for use in the experiment together with five Rich Points identified in each were trialled in a pilot study carried out in 2004 (reported in PACTE 2005a, 2005b). The Spanish source text used for inverse translation and the English source text used for direct translation are included in the appendix. The Rich Points selected are marked in each text, although they were not marked in the original texts that subjects were required to translate. The identification of these Rich Points by subjects forms part of the dependent variable "Identification and resolution of translation problems". 
The text used for inverse translation was the same for all subjects in both groups. It was translated into either French, German or English. The Rich Points (RP) identified were the following:

- RP1: El Indiano ... la fortuna del Americano (problem type: extralinguistic and textual)

- RP2: gobierno alfonsino (problem type: extralinguistic)

- RP3: desenfreno y dilapidación (problem type: linguistic)

- RP4: la geografía comarcal de Cataluña (problem type: intentionality)

- RP5: común ... trona (problem type: intentionality, textual y extralinguistic)

For the purposes of direct translation, parallel texts in English, French and German on the subject of computer viruses were used: "E-mail virus strikes in new form" (The Guardian, June 6, 2003), "Wurm in der Leitung" (Frankfurter Allgemeine Zeitung, June 14, 2003) and "Bugbear.B, le virus informatique qui lit par-dessus l'épaule de ses victimes" (Le Monde, June 13, 2003). To ensure that the RPs identified in the texts were comparable, the following categories of translation problems were selected:

- RP1: the title, which has a more or less marked metaphoric aspect in all three texts (problem type: intentionality)

- RP2: a technical term: keylogger // Download-Verzeichnis // édition de logiciels antivirus (problem type: extralinguistic)

- RP3: reference: doubled ... surge // Schädling ... E-mail- Würmer ... Vorgängervariante // Le ver ... résurgence ... ses congénères (problem type: textual)

- RP4: elements in apposition present in all three texts, from which certain elements could be omitted: a "Trojan horse" program which could allow a hacker to take remote control of infected machines // Dateien-Tauchbörse Kazaa // Soumissions, des communications du virus (problem type: textual and intentionality)

- RP5: particularly rich, with problems of comprehension and reformulation: Cheltenham-based virus filtering firm // Tastatureingaben von PC-Nutzern nach Kreditkartennummern und Ähnlichem überwacht // Enregistrer les caractères tapés sur le clavier (problem type: linguistic and intentionality)

Table 1 presents data concerning the most relevant aspects of our experimental design. 
Table 1. Dependent variables (adapted from PACTE 2005a, 2005b)

\begin{tabular}{|c|c|}
\hline \multicolumn{2}{|r|}{$\begin{array}{l}\text { KNOWLEDGE ABOUT TRANSLATION } \\
\text { Related to the knowledge about translation sub-competence }\end{array}$} \\
\hline $\begin{array}{l}\text { CONCEPTUAL } \\
\text { DEFINITION }\end{array}$ & $\begin{array}{l}\text { The subject's implicit knowledge about the principles of translation and aspects } \\
\text { of the translation profession }\end{array}$ \\
\hline INDICATORS & Dynamic index and coherence coefficient; acceptability \\
\hline INSTRUMENTS & Questionnaire on knowledge about translation \\
\hline DATA SOURCE & Subjects' answers to the questionnaire \\
\hline \multicolumn{2}{|r|}{$\begin{array}{l}\text { EFFICACY OF THE TRANSLATION PROCESS } \\
\text { Related to the strategic sub-competence }\end{array}$} \\
\hline $\begin{array}{l}\text { CONCEPTUAL } \\
\text { DEFINITION }\end{array}$ & $\begin{array}{l}\text { Optimum relationship between time taken to complete a translation task and the } \\
\text { acceptability of the solution }\end{array}$ \\
\hline INDICATORS & $\begin{array}{l}\text { Total time taken; time taken at each stage of the translation process (orientation, } \\
\text { development, revision); acceptability }\end{array}$ \\
\hline INSTRUMENTS & Translations, direct observation chart, PROXY and Camtasia recordings. \\
\hline DATA SOURCE & $\begin{array}{l}\text { Total time taken and time taken at each stage of the translation process in } \\
\text { relation to the acceptable and partially acceptable results obtained }\end{array}$ \\
\hline \multicolumn{2}{|c|}{$\begin{array}{c}\text { DECISION-MAKING } \\
\text { The most complex variable. It provides data on subjects' procedural behaviour } \\
\text { Related to strategic and instrumental sub-competences }\end{array}$} \\
\hline $\begin{array}{l}\text { CONCEPTUAL } \\
\text { DEFINITION }\end{array}$ & $\begin{array}{l}\text { Decisions made during the translation process which involve the use of } \\
\text { automatic and non-automatic cognitive resources (internal support) and the use } \\
\text { of different sources of documentation (external support) (Alves, 1995, 1997) }\end{array}$ \\
\hline INDICATORS & Sequences of actions; acceptability \\
\hline INSTRUMENTS & Translations, direct observation charts, PROXY and Camtasia recordings \\
\hline DATA SOURCE & $\begin{array}{l}\text { Sequences of actions leading to results that are acceptable, partially acceptable } \\
\text { and unacceptable in relation to "Rich Points". }\end{array}$ \\
\hline \multicolumn{2}{|r|}{$\begin{array}{l}\text { TRANSLATION PROJECT } \\
\text { Related to the strategic sub-competence }\end{array}$} \\
\hline $\begin{array}{l}\text { CONCEPTUAL } \\
\text { DEFINITION }\end{array}$ & $\begin{array}{l}\text { Mental representation or expectations of what the translation of a given text } \\
\text { should be like }\end{array}$ \\
\hline INDICATORS & $\begin{array}{l}\text { Dynamic index in the overall translation project and that of each Rich Point; } \\
\text { coherence between the overall translation project and that of each Rich Point; } \\
\text { acceptability }\end{array}$ \\
\hline INSTRUMENTS & Translation problems questionnaire and retrospective interview \\
\hline DATA SOURCE & Elements taken into account by the subject in relation to the translation brief \\
\hline \multicolumn{2}{|c|}{$\begin{array}{l}\text { IDENTIFICATION AND SOLUTION OF TRANSLATION PROBLEMS } \\
\text { Related to the knowledge about translation sub-competence and the strategic sub-competence }\end{array}$} \\
\hline $\begin{array}{l}\text { CONCEPTUAL } \\
\text { DEFINITON }\end{array}$ & Difficulties encountered by the subjects when carrying out a translation task \\
\hline INDICATORS & $\begin{array}{l}\text { Nature of problems identified, conceptualization of problems, solving procedure } \\
\text { as explained by the subject (sub-competence activated), subject's degree of } \\
\text { satisfaction with the solution found, degree of difficulty of the text; acceptability }\end{array}$ \\
\hline INSTRUMENTS & Translation problems questionnaire and retrospective interview \\
\hline DATA SOURCE & Problems identified and subjects' comments \\
\hline \multicolumn{2}{|r|}{$\begin{array}{l}\text { USE OF INSTRUMENTAL RESOURCES } \\
\text { Related to the instrumental competence }\end{array}$} \\
\hline $\begin{array}{l}\text { CONCEPTUAL } \\
\text { DEFINITION }\end{array}$ & $\begin{array}{l}\text { Process during which documentation strategies are activated using resources in } \\
\text { electronic format (webs, dictionaries and encyclopaedias in CD-ROM) }\end{array}$ \\
\hline INDICATORS & $\begin{array}{l}\text { Variety of resources, number of searches, time spent on searches (total and for } \\
\text { each phase); acceptability }\end{array}$ \\
\hline INSTRUMENTS & PROXY/Camtasia recordings, Catalogue of searches \\
\hline DATA SOURCE & $\begin{array}{l}\text { Phase(s) of the search/es; Time spent (initial/final); Categories of resources } \\
\text { (type, sub-type); Number of resources (variety of searches); Number of } \\
\text { searches (quantity of searches) }\end{array}$ \\
\hline
\end{tabular}


Our aim was to analyse data in a contrastive manner: translators and teachers; direct and inverse translation; different indicators; each indicator in conjunction with the indicator 'Acceptability'. In some cases, all data resulting from the experiment have been taken into account; in others, only the data relating to the RPs has been used.

\section{RESULTS}

Data obtained from our experiment is being analysed in the following order: "Knowledge about Translation"; 'Acceptability'; "Efficacy of the Process"; "Decisionmaking"; "Translation Project"; and "Identification and Solution of Problems". Data related to the use of instrumental resources is also being analysed. Inverse translation data are always analysed first, since the source text used is the same for all subjects, thus facilitating the development of models for the analysis of data which can be applied to all language pairs equally.

The methods used and the results obtained for "Knowledge about Translation", and "Efficacy of the Process" and "Acceptability' in inverse translation have been published in PACTE (2007a, 2007b, 2008). The results obtained for 'Acceptability' and the variable "Decision-making", in both direct and inverse translation, are described in the following sections.

\subsection{Acceptability}

'Acceptability' refers to translation product quality. The quantitative and qualitative analysis of the data collected in exploratory tests (PACTE 2002) and a pilot study (PACTE 2005a, 2005b) confirmed the importance of this indicator in measuring subjects' expertise in translation. It is the only indicator that measures all variables and it is used in conjunction with the specific indicators of each variable (see Table 1).

\subsubsection{Measuring the indicator 'Acceptability'}

In our research project, 'Acceptability' is defined in terms of whether or not the solution effectively communicates (a) the meaning of the source text; (b) the function of the translation (within the context of the translation brief, the readers' expectations, genre conventions in the target culture); and (c) makes use of appropriate language. 
Each translation solution given is classified as follows: Acceptable Solution (A), Semiacceptable Solution (SA), Non-Acceptable Solution (NA). Twenty-seven possible permutations were obtained by triangulating these categories (PACTE 2007b, 2008). Subsequently, numeric values were assigned to each category: $A=1 ; S A=0.5 ; \mathrm{NA}=0$ (Table 2). Finally, a descriptive analysis was made of the numerical values obtained for each RP, in both direct and inverse translation, and for each experimental group.

Table 2. Permutations, categories and numeric values for the indicator 'Acceptability'

\begin{tabular}{|c|c|c|c|c|}
\hline Meaning & Function & Language & Category & Numeric value \\
\hline A & A & A & \multirow{5}{*}{$\mathbf{A}$} & \multirow[t]{5}{*}{ 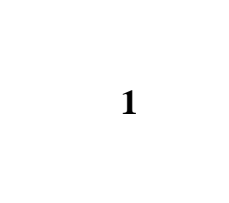 } \\
\hline A & A & SA & & \\
\hline A & SA & A & & \\
\hline A & SA & SA & & \\
\hline SA & A & A & & \\
\hline $\mathrm{A}$ & $\mathrm{A}$ & NA & \multirow{7}{*}{ SA } & \multirow{7}{*}{0.5} \\
\hline A & SA & NA & & \\
\hline A & NA & A & & \\
\hline A & NA & SA & & \\
\hline SA & SA & A & & \\
\hline SA & SA & SA & & \\
\hline SA & A & SA & & \\
\hline A & NA & NA & \multirow{3}{*}{ NA } & \multirow{3}{*}{$\mathbf{0}$} \\
\hline SA & SA & NA & & \\
\hline etc. & & & & \\
\hline
\end{tabular}

\subsection{2. 'Acceptability' obtained for each 'Rich Point'}

Figure 1 shows the mean values obtained for the indicator "Acceptability of the Results" for each RP for each experimental group (teachers and translators) in direct translation.

Figure 1. 'Acceptability' for each Rich Point in direct translation 


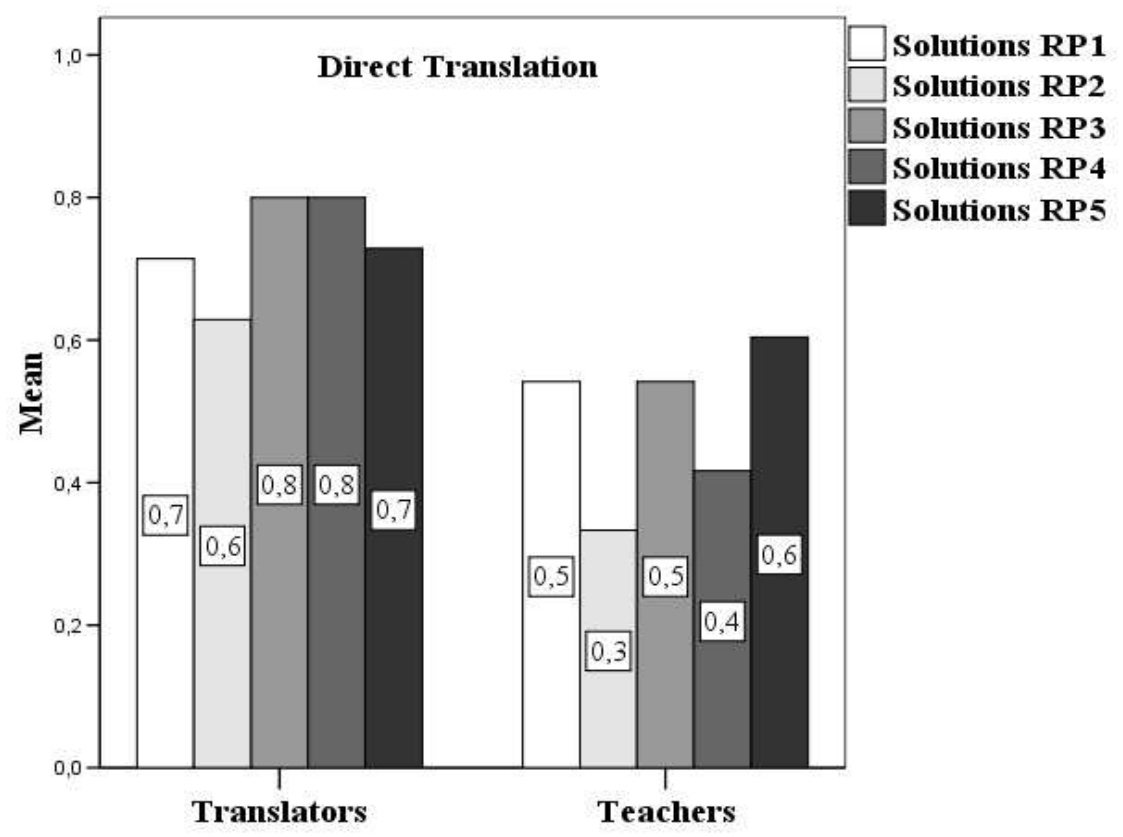

In direct translation, the best overall results can be observed in the group of translators. In some cases, however, the acceptability of the results is fairly similar in both groups depending on the characteristics of the RPs in question. For example, the results for RP2 (terminological; problem type: extralinguistic) were poorest in both groups; whilst the results for RP3 (reference; problem type: textual) and RP5 (problem type: linguistic and intentionality) were the best in both groups.

In inverse translation (Fig. 2), the inter-group differences are less conspicuous, although the translators' performance was somewhat better. As in the case of direct translation, the acceptability obtained for specific RPs was similar in both groups. Thus, results for RP1 (problem type: textual and extralinguistic) and RP4 (problem type: intentionality) were poorest in both groups, whereas results for RP2 (problem type: extralinguistic) and RP3 (problem type: linguistic) were the best in both groups.

Figure 2. 'Acceptability' for each Rich Point in inverse translation 


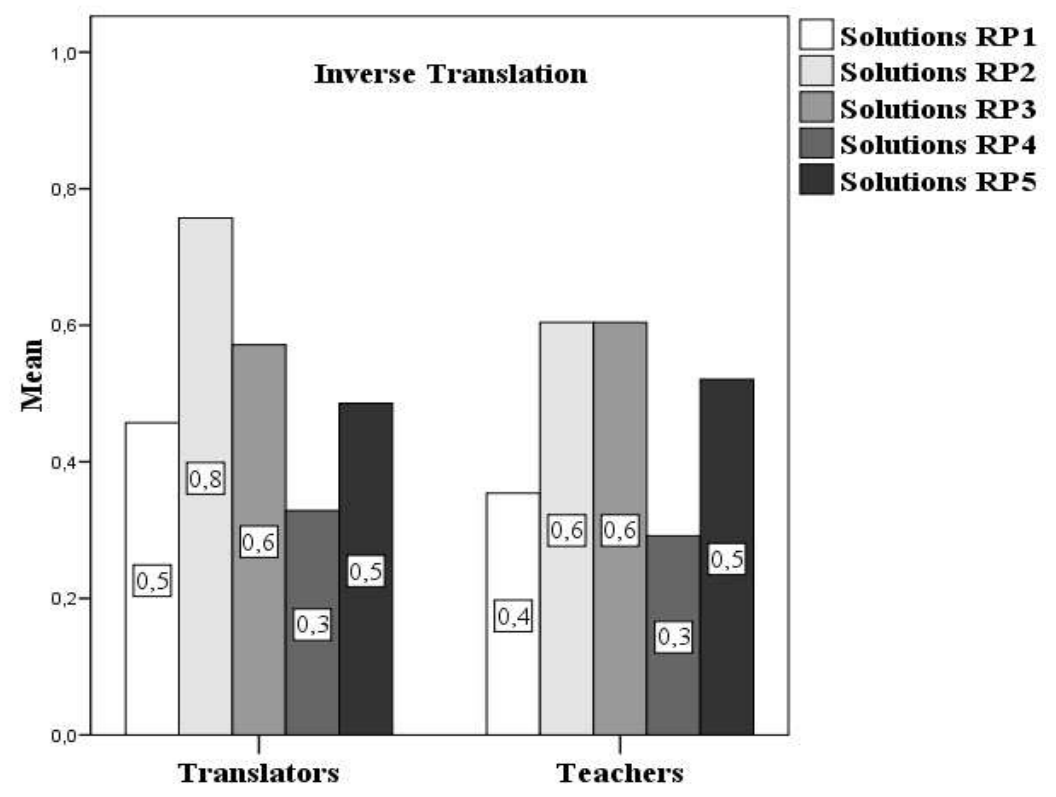

\subsection{3. 'Acceptability' obtained for each subject}

Once a numeric value was assigned to the acceptability of the solution to each RP, the mean acceptability of the solution found for each problem was calculated for each subject, first in inverse and then in direct translation. Then the overall mean acceptability for each subject was calculated in both direct and inverse translation.

Table 3 shows, ranging in order from highest to lowest, the mean acceptability of the results obtained for the top 17 subjects in the experimental group of translators (50\% of the total number; column 1) and the top 12 subjects in the group of teachers (50\% of the total number; column 2) in direct and inverse translation. The overall results for both groups of subjects in direct and inverse translation are presented in column 3. 
Table 3. 'Acceptability' obtained for each subject in direct and inverse translation Reference to each subject is encoded as follows: TR 1-34 (translator), P 1-24 (teacher); I (English); A (German), F (French)

\begin{tabular}{|c|c|c|c|c|c|}
\hline \multirow[b]{3}{*}{ RANKING } & \multirow{2}{*}{\multicolumn{2}{|c|}{$\begin{array}{l}\text { COLUMN } 1 . \\
\text { TRANSLATORS }\end{array}$}} & \multirow{2}{*}{\multicolumn{2}{|c|}{$\begin{array}{l}\text { COLUMN } 2 . \\
\text { TEACHERS }\end{array}$}} & \multirow{3}{*}{$\begin{array}{c}\text { COLUMN } 3 . \\
\text { TRANSLATORS } \\
\text { and TEACHERS } \\
\text { DIRECT and INVERSE } \\
\text { TRANSLATION: } \\
\text { Subject (Mean } \\
\text { Acceptability) } \\
\end{array}$} \\
\hline & & & & & \\
\hline & $\begin{array}{c}\text { DIRECT } \\
\text { TRANSLATION: } \\
\text { Subject (Mean } \\
\text { Acceptability) }\end{array}$ & $\begin{array}{c}\text { INVERSE } \\
\text { TRANSLATION: } \\
\text { Subject (Mean } \\
\text { Acceptability) }\end{array}$ & $\begin{array}{c}\text { DIRECT } \\
\text { TRANSLATION: } \\
\text { Subject (Mean } \\
\text { Acceptability) }\end{array}$ & $\begin{array}{c}\text { INVERSE } \\
\text { TRANSLATION: } \\
\text { Subject (Mean } \\
\text { Acceptability) }\end{array}$ & \\
\hline 1 & TRI12 (1.00) & TRI12 (1.00) & PI9 $(0.90)$ & PI1 $(0.90)$ & TRI12 (1.00) \\
\hline 2 & TRF10 (1.00) & TRF5 (1.00) & PI1 (0.80) & PI9 (0.80) & TRF10 $(0.90)$ \\
\hline 3 & TRI8 (1.00) & TRA4 (1.00) & PA7 (0.80) & PF5 (0.80) & PI1 (0.85) \\
\hline 4 & TRI7 (1.00) & TRF10 (0.80) & PI8 (0.80) & PA7 (0.70) & TRF4 (0.85) \\
\hline 5 & TRI3 (1.00) & TRF4 (0.80) & PI7 (0.70) & PA4 (0.70) & PI9 (0.85) \\
\hline 6 & TRF4 (0.90) & TRF2 (0.80) & PF6 (0.70) & PF2 (0.70) & TRF5 (0.80) \\
\hline 7 & TRI14 (0.90) & TRI14 (0.70) & PI2 (0.70) & PA5 (0.60) & TRA4 $(0.80)$ \\
\hline 8 & TRI4 (0.90) & TRA3 (0.70) & PA4 (0.60) & PI8 (0.50) & TRI14 (0.80) \\
\hline 9 & TRF8 (0.90) & TRA2 (0.70) & PA6 (0.60) & PI3 (0.50) & TRF2 (0.75) \\
\hline 10 & TRA3 (0.80) & TRA9 (0.70) & PF8 (0.60) & PI4 (0.50) & TRA3 (0.75) \\
\hline 11 & TRI1 (0.80) & TRI13 (0.70) & PF4 (0.60) & PA2 (0.50) & PA7 (0.75) \\
\hline 12 & TRI11 (0.80) & TRI1 (0.60) & PF7 (0.50) & PI7 (0.40) & TRA2 (0.70) \\
\hline 13 & TRF11 (0.80) & TRI11 (0.60) & & & TRA9 $(0.70)$ \\
\hline 14 & TRI15 (0.80) & TRF11 (0.60) & & & TRI1 $(0.70)$ \\
\hline 15 & TRI9 (0.80) & TRI6 (0.60) & & & TRI11 $(0.70)$ \\
\hline 16 & TRF3 $(0.80)$ & TRI15 (0.50) & & & TRF11 (0.70) \\
\hline 17 & TRA1 $(0.80)$ & TRA7 (0.50) & & & TRI8 (0.70) \\
\hline
\end{tabular}

Only nine of the 17 translators (26\% of the total number of translators; $53 \%$ of the top 17) with the highest mean acceptability for direct translation obtained a similar degree of acceptability in inverse translation (Table 3, column 1, in bold). Similarly, only six of the twelve teachers ( $25 \%$ of the total number of teachers, $50 \%$ of the top twelve) with the highest mean acceptability for direct translation obtained a similar degree of acceptability in inverse translation. (Table 3; column 2, in bold). This suggests that a high degree of acceptability of the results obtained in direct translation does not automatically presuppose an equally high degree of acceptability in inverse translation.

When the overall mean acceptability was obtained for both groups of subjects in direct and inverse translation (column 3), it was observed that 14 subjects from the group of translators, as opposed to three from the group of teachers, figured amongst the 17 subjects with the highest mean acceptability. This would appear to confirm our general hypothesis that the degree of expertise in translation affects the translation product.

The indicator 'Acceptability' evidenced the presence of three subjects from the group of foreign-language teachers who, according to our definition of expertise in translation, obtained a degree of acceptability of the overall results in translation (direct and inverse translation) similar to that of the best translators. The results obtained for 
other variables should be examined to determine whether or not these subjects may effectively be considered to be experts in translation.

\subsubsection{Acceptability obtained for each experimental group}

Calculating the mean acceptability for each experimental group sheds light on the quality of the solutions found by subjects in each group for each RP. Table 4 and Figure 3 show the results of the descriptive analysis of the data.

Table 4. 'Acceptability', for each experimental group, in direct and inverse translation

\begin{tabular}{|l|l|r|r|}
\hline & $\begin{array}{c}\text { Acceptability } \\
\text { of Results }\end{array}$ & Translators & \multicolumn{1}{|c|}{ Teachers } \\
\hline Direct & Mean & 0.73 & 0.49 \\
Translation & Median & 0.80 & 0.45 \\
\hline Inverse & Mean & 0.52 & 0.48 \\
Translation & Median & 0.50 & 0.40 \\
\hline
\end{tabular}

The group of translators obtained the best results in direct translation with a mean value 0.73. These results were considerably better than those obtained by the same group in inverse translation (mean value 0.52) and those obtained by the group of teachers in both direct (0.49) and inverse (0.48) translation. The quality of the results obtained by the group of translators in direct translation is particularly worthy of note.

The acceptability of the results obtained by the group of translators in inverse translation was, however, only slightly better than the results obtained by the group of teachers. Given that only $48 \%$ of the group of translators reported having any experience in inverse translation, most of the translators were probably not involved in text production in the foreign language on a regular basis whilst teachers, on the other hand, were no doubt involved in foreign-language text production on a daily basis. The fact that the translators' performance was slightly better than that of the teachers, despite their lack of practice in foreign text production, may indicate that translators somehow compensate for their shortcomings in the foreign language by activating other sub-competences. 
Figure 3. 'Acceptability', for each experimental group, in direct and inverse translation

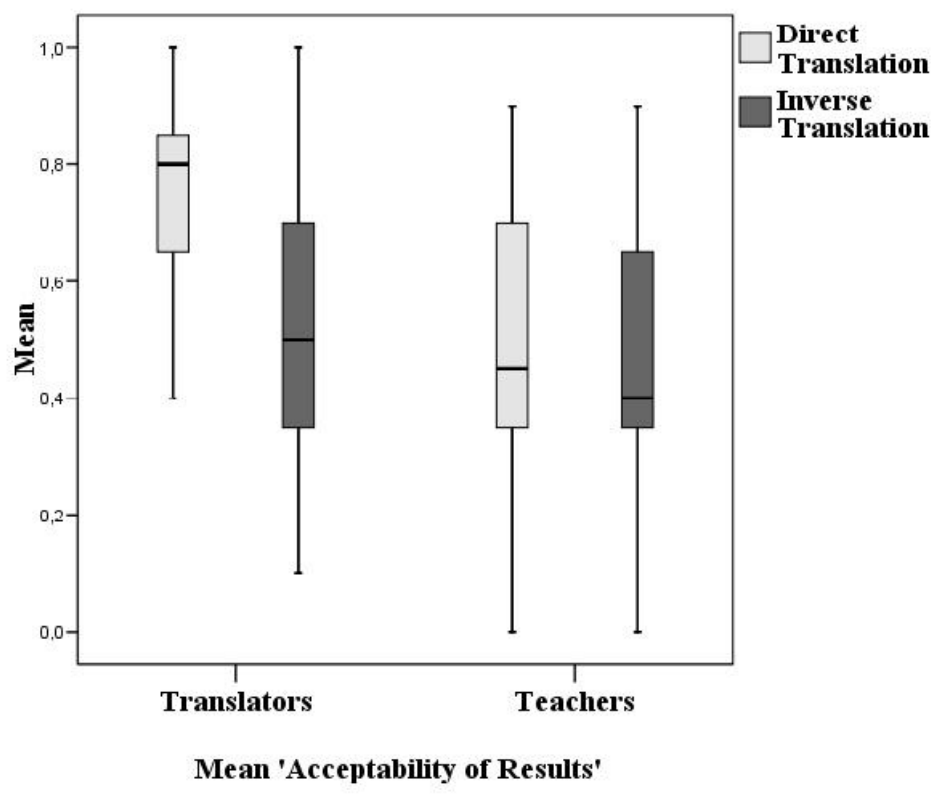

\subsection{DECISION-MAKING}

The variable "Decision-making" provides data on subjects' procedural behaviour, understanding the process of decision-making as that of activating sub-competences while carrying out a translation task. The sources of data used are: the target texts, direct observation charts, and PROXY as well as and Camtasia recordings. Indicators include 'Sequences of Actions' and 'Acceptability'.

This variable reflects strategic and instrumental sub-competences. Activating these competences involves both internal and external support (Alves 1995, 1997), the former implying use of automatic and non-automatic cognitive resources and the latter the use of different sources of documentation.

\subsubsection{Measuring Sequences of Actions}

The exploratory tests and the pilot study carried out prior to our experiment on translation competence evidenced different actions performed by translators during the translation process (PACTE 2002). Of these, the actions considered most relevant to our study were those leading to: Provisional Solutions to translation problems; Definitive Solutions to translation problems; and Consultation of different documentary resources. For the analysis of the data obtained from the experiment, consultations were divided 
into three different categories depending on the degree of subjects' cognitive implication in each:

1. Consultation of bilingual resources: non-specialist bilingual dictionaries, specialist bilingual dictionaries and glossaries; bilingual and multilingual databases in general. This category is one in which there is little cognitive implication on the part of subjects as this is limited to accepting or rejecting the variant offered.

It is further sub-divided into: (a) consultation of bilingual resources, with the variant offered accepted in the translation; and (b) consultation in bilingual resources, but without the variant offered accepted in translation.

2. Consultation of alternative resources. Subjects' cognitive implication is greater as a choice must be made between different possible translation solutions.

3. No consultations.

Our exploratory tests and pilot study show that, when solving translation problems, these actions combine to form different sequences depending on the degree of internal and/or external support used. Accordingly, four different categories of sequences were established, depending on the type of support used (Figure 4):

- Internal Support: the Definitive Solution is based exclusively on internal support, with no consultation prior to the Definitive Solution being adopted. Example: Definitive Solution; Provisional Solution $\rightarrow$ Definitive Solution

- Predominantly Internal Support: the Definitive Solution is based essentially on internal support, i.e., any combination of consultations which does not include a consultation of bilingual resources from which the variant offered is adopted in translation. Example: Provisional Solution $\rightarrow$ Consultation of Alternative Resources $\rightarrow$ Consultation of Alternative Resources $\rightarrow$ Consultation of Bilingual Resources (but the variant is not adopted in the translation) $\rightarrow$ Definitive Solution

- Predominantly External Support: the Definitive Solution is based essentially on external support, i.e., any combination of consultations that includes consultations of bilingual resources from which the variant offered is adopted in translation. Example: Provisional Solution $\rightarrow$ Consultation of Alternative 
Resources $\rightarrow$ Consultation of Alternative Resources $\rightarrow$ Consultation of Bilingual Resources (and the variant offered is adopted in the translation) $\rightarrow$ Definitive Solution

- External Support: the Definitive Solution is based exclusively on consultation of bilingual resources, from which the variant offered is accepted in the translation. Example: Consultation in Bilingual Resources (and the variant offered adopted in translation) $\rightarrow$ Definitive Solution

Figure 4. Cognitive implication in sequences of actions (adapted from PACTE 2005a, 2005b, 2007a, 2007b)

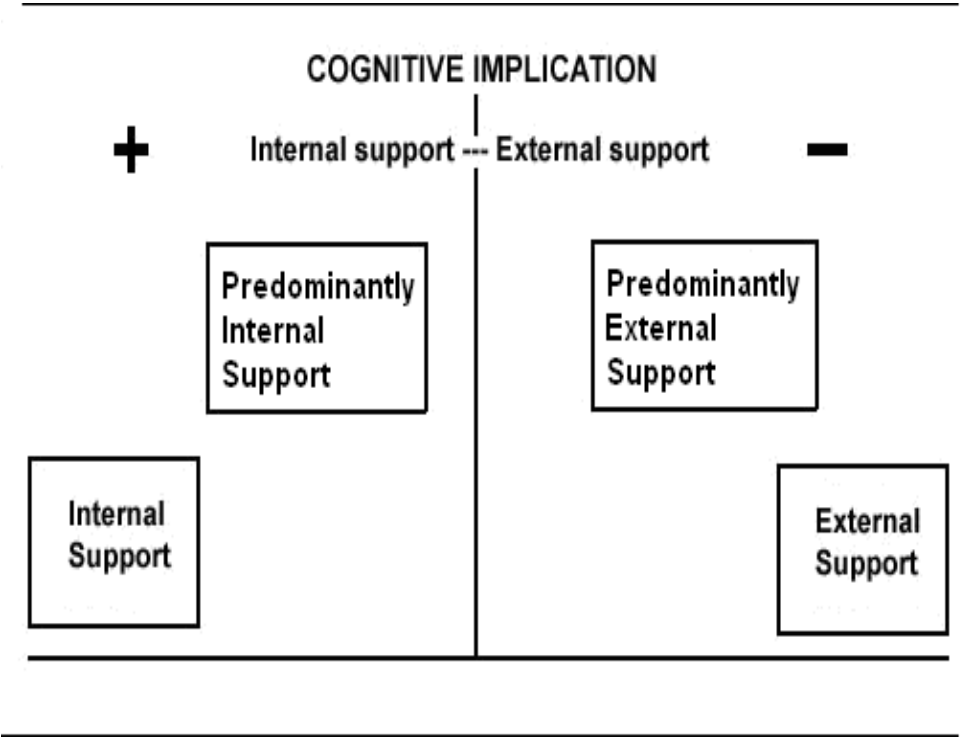

\subsubsection{Results obtained for 'Sequences of Actions'}

The descriptive analysis of the 'Sequences of Actions' evidenced the type of support most often used (internal or external) by each experimental group in direct translation and in inverse translation.

In direct translation, the following results were obtained:

- Internal Support was used much more often by teachers $(52.5 \%)$ than by translators $(36.5 \%)$.

- Predominantly Internal Support was used much more often by translators $(42.4 \%)$ than by teachers $(29.2 \%)$.

- Predominantly External Support was used more often by translators (15.3\%) than teachers $(11.7 \%)$. 
- External Support was used slightly more by teachers $(6.7 \%)$ than by translators $(5.9 \%)$.

In inverse translation, the results obtained showed that:

- Internal Support was used much more often by teachers $(31.7 \%)$ than by translators $(13.9 \%)$.

- Predominantly Internal Support was more often used by translators (41.8\%) than by teachers $(31.7 \%)$.

- Predominantly External Support was used more often by translators (25.5\%) than teachers $(18.3 \%)$.

- External Support was used equally by translators $(18.8 \%)$ and teachers $(18.3 \%)$.

The conclusions that may be drawn from the sequences of actions observed in teachers and translators in inverse and direct translation are the following:

- The use of Internal Support was more characteristic of teachers.

- Predominantly Internal Support was more characteristic of translators.

- Predominantly External Support was used more often in inverse translation than in direct translation by both groups.

- External Support was used much more often in inverse translation than in direct translation by both groups.

\section{2.3. Results obtained for 'Sequences of Actions' and 'Acceptability' (per group)}

When 'Sequences of Actions' were analysed in conjunction with 'Acceptability', the following conclusions were drawn:

- In Direct Translation, translators, who had much more acceptable results than teachers (see section 4.1.4.), used Predominantly Internal Support (47.3\%) whilst teachers used Internal Support $(63.7 \%)$ to obtain best results.

- In Inverse translation, Predominantly Internal Support was used by both groups to obtain acceptable solutions (Translators $51.9 \%$; Teachers $38.6 \%$ ).

The degree of acceptability was greatest when a combination of internal support and consultation of monolingual resources was used; hence the importance of instrumental competence. 


\subsubsection{Results obtained for 'Sequences of Actions' and 'Acceptability' (for each Rich Point)}

As a result of triangulating the results, it was noted that (a) each experimental group used different sequences of actions to solve the same problem and (b) the type of translation problem posed by each RP determined the most successful sequence of action.

In direct translation, an example illustrative of the tendency of both experimental groups to use different sequences of actions to solve the same problem is RP1 (the title - problem type: intentionality). Most of the Acceptable Solutions found by translators for this RP were the product of Predominantly Internal Support (52.4\%), whilst most of the Acceptable Solutions found by teachers were the product of Internal Support $(55.6 \%)$.

In inverse translation, the sequences of actions used by each experimental group varied greatly depending on the characteristics of each RP.

Thus, most of the Acceptable Solutions found by translators for RP2 (gobierno alfonsino - problem type: extralinguistic) were the product of Predominantly Internal Support $(73.7 \%$ ), whilst most of the Acceptable Solutions found by the teachers were the product of Internal Support (72.7 \%). In RP4 (geografía comarcal - problem type: intentionality) Acceptable Solutions in both groups were the product of Internal Support (50\%) and Predominantly Internal Support (50\%). In RP3 (desenfreno y dilapidación

- problem type: linguistic), External Support was used by translators to obtain Acceptable Solutions in $35.7 \%$ of cases and by teachers in $40 \%$ of cases (when it came to linguistic problems, consultation of bilingual dictionaries was predominant in both groups).

\section{Conclusions}

Several conclusions may be drawn with regard to the nature of translation competence as a result of the analysis of data obtained from the indicator 'Acceptability'. These conclusions would appear to validate the PACTE model of Translation Competence (PACTE 2000, 2003): 
1. Subjects whose translations were most acceptable (in direct and inverse translation) belonged to the group of translators. In direct translation, the results obtained by translators were much better than those of the group of teachers. This would appear to confirm our initial hypothesis that expertise in translation affects the final product (the quality of the translation).

2. The fact that a subject obtains acceptable results in direct translation does not mean that s/he will obtain acceptable results in inverse translation. Only approximately $25 \%$ of subjects obtained acceptable results in both direct and inverse translation. This was most apparent in the case of the group of translators, who obtained much better results in direct translation than in inverse translation. This would indicate a difference between the way in which translation competence functions when translating into or out of the foreign language.

3. Although more than half of the group of translators professed to having no experience of translation into the foreign language, and presumably, therefore, had little experience of text production in the foreign language, they nevertheless obtained equally acceptable results in inverse translation when compared with the group of foreign-language teachers who, although they had no experience in translation, were most familiar with foreign-language text production. Indeed, when results for inverse translation were analysed in both groups, the translators who produced the most acceptable results obtained far better results in inverse translation than the teachers did. This would indicate that the translators' lack of experience in foreign-language text production was compensated by activating other sub-competences of translation competence (strategic, instrumental, knowledge of translation) to obtain better results. This would appear to confirm not only the interrelation of sub-competences proposed in our model of translation competence, but also the predominant role of strategic competence in compensating for apparent shortcomings in other sub-competences (in this case, linguistic and extralinguistic). The ability to optimize performance by compensating for shortcomings in sub-competences would thus constitute a characteristic of expertise in translation.

The following conclusions may be drawn from results obtained for the variable "Decision-making": 
1. During the translation process different sequences of actions take place ranging from the use of more internal support to the use of more external support, depending on the degree of the subjects' cognitive implication. These sequences have been classified by PACTE as: Internal Support, Predominantly Internal Support, Predominantly External Support, and External Support.

2. Depending on the type of translation problem encountered, subjects use different sequences of actions, involving varying degrees of external support, to find a solution. This would indicate that, depending on the nature of the difficulties experienced, subjects activate certain sub-competences as opposed to others.

3. Each group of subjects uses one sequence of actions more than another. Internal Support is more characteristic of teachers and Predominantly Internal Support is more characteristic of translators. This would indicate that the instrumental subcompetence is not as highly developed amongst teachers as amongst translators, who use external support much more often both in direct and inverse translation (excluding consultations of bilingual resources from which the variant is not adopted). Instrumental competence may therefore be considered to constitute a further characteristic of expertise in translation.

4. The highest degree of acceptability of translation solutions occurs in the group of translators and is obtained using a combination of internal and external support: Predominantly Internal Support. The element of external support involved in this sequence takes the form of consultations in different types of resources. This confirms the importance, within translation competence, of the strategic sub-competence (which activates all other sub-competences) and the instrumental sub-competence. It also evidences the relationship between a dynamic concept of translation in expert translators (PACTE 2008) and the type of sequence of actions used in the translation process in the search for dynamic solutions instead of static solutions, directly adopted into translation from bilingual resources.

5. Predominantly External Support was used more often in inverse translation than in direct translation by both groups, and External Support was used much more often in inverse translation than in direct translation by both groups. This would indicate that shortcomings in linguistic and extralinguistic sub-competences, since subjects are translating into a language which is not their own, is 
compensated by instrumental competence. This finding supports the conclusion (see conclusion 2 for acceptability) that there is a difference between the way in which translation competence functions when translating into or out of the foreign language.

It should be noted that these conclusions will be contrasted with the results obtained from other variables to verify the tendencies observed. The PACTE Group is currently completing its analysis of data obtained from the questionnaire on translation problems and the retrospective interview (instruments that provide data on the variables "Translation Project" and "Problems Identification and Resolution"). We are also triangulating the results obtained for different variables and carrying out more in-depth analysis of the use of instrumental resources in the translation process given that marked differences have been observed between experts and non-experts. Once we have completed this stage of our research, we will begin the second phase: the empirical study of the process of acquisition of translation competence.

\section{REFERENCES}

Alves, F. 1995. Zwischen Schweigen und Sprechen: Wie bildet sich eine transkulturelle Brücke? Eine Analyse von Übersetzungsvorgängen zwischen portugiesischen und brasilianischen Übersetzern. Hamburg: Dr. Kovac.

Alves, F. 1997. A formação de tradutores a partir de uma abordagem cognitiva: reflexões de um projeto de ensin. TradTerm. Revista do Centro Interdepartamental de Tradução e Terminologia. 4-2. 19-40.

Jakobsen, A. 2002. Orientation, Segmentation, and Revision in Translation. In: Hansen, G. (ed.) Empirical Translation Studies: Process and Product. Copenhagen Studies in Language Series 2. Copenhagen: Samfundslitteratur. 191-204.

Neinzig, W. 2002. Estudios empíricos en Traducción: Apuntes Metodológicos. Cadernos de Tradução: $O$ processo de Tradução 10. 75-96.

PACTE. 2002. Exploratory tests in a study of translation competence, Conference Interpretation and Translation. 4(2). 41-69.

PACTE. 2003. Building a Translation Competence Model, In: Alves, F. (ed.) Triangulating Translation: Perspectives in process oriented research. Amsterdam: John Benjamins. 43-66.

PACTE. 2005a. Primeros resultados de un experimento sobre la Competencia Traductora. In: Actas del II Congreso Internacional de la AIETI (Asociación Ibérica de Estudios de Traducción e Interpretación) Información y documentación. Madrid: Publicaciones de la Universidad Pontificia Comillas, 573-587. CD-ROM. 
PACTE. 2005b. Investigating Translation Competence: Conceptual and Methodological Issues. Meta. 50-2, 609-619.

PACTE. 2007a. Zum Wesen der Übersetzungskompetenz. Grundlagen für die experimentelle Validierung eines Ük-Modells. In: Wotjak, G. (ed.) Quo vadis Translatologie? Ein halbes Jahrhundert universitärer Ausbildung von Dolmetschern und Übersetzern in Leipzig. Rückschau, Zwischenbilanz und Perspektiven aus der Außensicht. Berlin: Frank \& Timme. 327-432.

PACTE. 2007b. Une recherche empirique expérimentale sur la compétence en traduction. In: Gouadec, D. (ed.) Actes du Colloque International: Quelle formation pour le traducteur?. París: La Maison du dictionnaire. 95-116.

PACTE. 2008. First Results of a Translation Competence Experiment: 'Knowledge of Translation' and 'Efficacy of the Translation Process'. In: Kearns, J. (ed.) Translator and Interpreter Training. Issues, Methods and Debates. London: Continuum. 104-126.

\section{APPENDIX \\ INVERSE TRANSLATION TEXT}

\section{La Plana Novella}

La Plana Novella es una antigua heredad adquirida por el 1Indiano Pere Domenech i Grau en 1885 que se encuentra en una pequeña planicie en el centro del Parc Natural del Garraf y pertenece al municipio de Olivella. La Finca fue declarada colonia agrícola 10 años más tarde por el 2 gobierno alfonsino, pero de aquella época

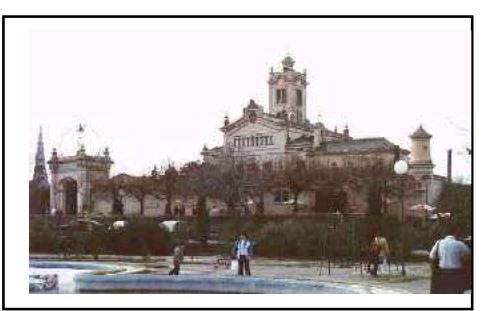
perdura una leyenda de 3desenfreno y dilapidación que hizo desaparecer la 1fortuna del americano. El estilo arquitectónico del Palacete es ecléctico, es decir que mezcla diferentes estilos. 4La geografía comarcal de Cataluña lo califica de "Castillo de Bambalinas" como si fuese un decorado de teatro. Sin ningún tipo de duda la construcción estilísticamente más original de Palau Novella es el lavadero gaudiniano, pero una de las piezas más características y llamativas del Palau es el 5común, conocido como 5"la trona".

http://www.laplananovella.

\section{DIRECT TRANSLATION TEXT}

\section{Email virus strikes in new form}

Computer users were warned last night to be on the lookout for an email virus that can steal confidential information and allow hackers to take control of infected machines. The virus, a new variant of the BugBear email worm that infected tens of thousands of computers around the world last October, began to spread rapidly from Australia to Europe and the USA at around 8am yesterday. According to MessageLabs, a 5Cheltenham-based virus filtering firm which reported about 30,000 infected messages in 115 countries, the 3propagation rate of BugBear.B almost 3doubled every hour throughout the morning. There was also a huge 3surge as US users came online. Like its predecessor, the variant spreads by sending itself as an attachment to every address in an infected machine's email address book. To disguise where it came from, it uses different subject headings. As well as searching for anti-virus software and disabling it, BugBear.B installs a 2keylogger to record what the user types, which may allow hackers to record confidential information such as credit card details and passwords. It also installs a 4"Trojan horse" program which could allow a hacker to take remote control of infected machines. [...] 